\title{
Marketing Strategic Planning and Choosing the Right Strategy using AHP Technique (Case Study: Ghavamin Bank Mazandaran)
}

\author{
Forough Sadeghpour ${ }^{1 *}$, Mohammad Ghorbani Far ${ }^{2}$, Ali Ramzan Khah ${ }^{3}$, \\ Masoumeh Amu Akbardokht Amiri 4
}

\begin{abstract}
${ }^{1}$ MA Student of Executive Management, Management, Economics and Accounting, Payam Noor University, IRAN
${ }^{2}$ Mazandaran Branch Management, Expert of Research and Market Development, MA, Governmental Management, IRAN

${ }^{3}$ Mazandaran Branch Management, The Charge Expert of Credits, $M A$, Governmental Management, IRAN

${ }^{4} \mathrm{MA}$ student, Department of English Language and Literature, Central Tehran Branch, Islamic Azad University, Tehran, IRAN
\end{abstract}

\section{*Corresponding Author: Sadeghpour.foroogh@gmail.com}

Citation: Sadeghpour, F., Far, M. G., Khah, A. R. and Akbardokht Amiri, M. A. (2017). Marketing Strategic Planning and Choosing the Right Strategy using AHP Technique (Case Study: Ghavamin Bank Mazandaran). Dutch Journal of Finance and Management, 1(2), 45. https://doi.org/10.29333/djfm/5821

Published: July 3, 2017

\begin{abstract}
The main purpose of this study was to identify the right strategy marketing plan Ghavamin Bank in Mazandaran province Analytical Hierarchy Process (AHP) have been. The study of the target application, based on the nature and control variables descriptive non-experimental research is quantitative data that is collected by Operations Research. Due to the above, this study is a descriptive survey research. Study the Analytical Hierarchy Process (AHP) Was to gather information through questionnaires paired comparison Comments 15 experts to decide and prioritize factors have been taken. The results showed that by hierarchical validity and reliability of research tools for measuring components has been desired. In determining the priority of various factors, the results showed that the factors that should be prioritized in the strategic planning of marketing Ghavamin Bank considered by managers include: economic factors, competition, communication with customers and prospects, and future plans.
\end{abstract}

Keywords: strategic planning, marketing, strategic planning, marketing, Ghavamin Bank Mazandaran

\section{INTRODUCTION}

Planning on other duties is priority and precedence over them. So if we consider the duty manager to the pyramid, it is planned to put on the top. Of course, all the duties of a manager are related, but among them are planning a priority. So we can say that, in fact, planning, task management foundation. The setting for a variety of applications and in a manner commensurate with its status Frakhvrd form. It could say that's the definition of planning is to estimate future needs and identify resources to meet those needs. In other words, planning decisions about what should be done and how it should be done. Planning is a process in which the production, circulation and coordination of information on the degree of decision-making is to be organized. Planning decisions in the form of common but coordinated series of decisions taken in the planning process are produced. Planning can be done now or in the future. Planning is the process of identifying and interconnected steps to produce a consistent output in the form of a coordinated system of decisions (Rahman nature, 2004). According to the definition of cross-sectional and fragmented decision-making and policies to promote the organization now or in the future are 
planned. Although some companies and organizations have no future plans in mind and ensure its survival. Planning process can be used to guide the organization.

Basically, two types of programs run by the organization: strategic plans and operational plans, strategic objectives of the organization and the operational program or action plan, a detailed description of the strategic plan in the form of everyday politics are. Although there are differences between strategic and operational plans, but it was not clear border, because what is an operational decision, it is possible for someone else to be strategic, so the difference between them is a matter of relative, not absolute (Samadi and Fine, 2009). Strategic planning is a type of program where the goal is to define and develop a strategy. Since the strategy can be short or long-lived. Strategic planning can be long-term or short-term planning, but it is different from. The marketing and management market, one of the most important branches of knowledge management that his main task is to identify the need and demands. and eliminate them through the process of exchange of human resources, because modern societies are more than ever the one hand, the needs, particularly with the increasing demands of human faces and on the other hand, faced with a lack of resources and management have limited resources available to meet the demands of the people and the unlimited knowledge management is to help economics and a set of skills and knowledge to optimize the use of limited resources and marketing as well as the need to remove it will appoint an effort by exchanging resources (Venus and Jazani Khani, 2007).

One of the important activities in the success of organizations and companies, especially financial institutions gain a competitive advantage through the marketing and implementation of sound policies in this field. According to Gungaphul and Boolaky marketing is the process of planning and implementing the basic idea, pricing, promotion and distribution of ideas, products and services to create exchanges that realize individual and organizational goals (Gungaphul and Boolaky, 2009). Drucker believes that a much broader marketing and sales activity that is specific to a particular unit, but the entire set of business involved (Horner and Swarbrook, 2005). If the organization has a strategic plan and marketing can be organized in today's competitive market and a competitive advantage over its competitors surpassed the otherwise lost to competitors and competition is virtually out of the picture. Given the importance of planning, especially strategic planning affairs in the success of the organization and discussed above, the present study sought to answer this question properly planned marketing strategy in the province Ghavamin Bank of Analytical Hierarchy Process (AHP) What?

\section{History and Explanation of the Research Question}

The results of Sadeghi et al (2011) showed effectiveness analysis of the effectiveness of strategic planning, marketing information systems (Case banks, showed that the information content and form, respectively, the highest and lowest levels of the explanatory process of change and strategic planning. The elements of the strategic planning process, analyzing the situation and the allocation of resources and targeted the most and then set goals and develop strategies with marketing information systems have the least influence on the output. The results of the study showed that among the components of the marketing mix, the beauty and appearance of products and variety of products, installment sales and discounts offered to distributors, buyers and deliver the appropriate products in a timely fashion and promote the tiles conservatives and Mass and advertising in professional journals (respectively corresponding to the product, price, distribution and promotion) had the highest priority. Abdul research findings (2013) as the strategic planning of marketing in the banking industry in Nigeria, showed that banks are to succeed in a competitive market and develop its services and prevent corruption in the economic market needs a good program and appropriate marketing strategy.

This program, several issues must be considered, especially environmental issues and market situation. The intelligent monitoring of the strengths, weaknesses, opportunities and threats of the bank can help in strategic planning, marketing is appropriate. Pistol (2010) in a study showed examines the role and importance of strategic planning and marketing has made banks. Finally, the researchers concluded that the most important factors in decision-making and strategic planning to ensure a competitive advantage Bank Marketing include customer feedback to modern banking services, and assumptions about customers. The results of Claycomb et al (2000) as the impact of marketing strategic planning on the configuration, structure, and performance of industrial wire patterns indicated that strategic planning, marketing has officially increased integration, specialization, and decentralized companies, supervision according to internal metrics, performance and success in the market is competitive and better financial performance. Based on the discussions and examine records, this study sought to answer the following questions:

1. Factors in the strategic planning of marketing in the province are Ghavamin Bank?

2. Prioritize factors in strategic planning, marketing Ghavamin Bank is the province? 


\section{METHODOLOGY}

The practical purpose of this research is to try based on theories, laws, etc. to develop the method to solve practical problems and real practice. The results of this applied research to facilitate the implementation and it is used to solve problems. The nature and mode of control variables descriptive non-experimental research has been done to the survey. This research is quantitative data that were collected by Operations Research. Due to the above, this study is a descriptive survey research. Since the data collection method is the Delphi study, the first to identify the experts, the people who have expertise and experience in the banking and electronic banking were high, then the action through the open questionnaire and to gather information identify the factors affecting marketing strategic planning Ghavamin Bank action, and these were classified. To collect information from the library and field method is used. In library use and reading books and articles have been attempted. In addition, field methods to identify factors in the strategic planning of marketing action that questionnaire with 15 questions to the experts was open and it was asked to strategic marketing planning factors in the list. The common and different response obtained and was categorized on theoretical grounds. Data from the second part of each of the questionnaires in descriptive tables using SPSS software The frequency and relative frequency with comparative charts and analysis matrix is then paired comparisons between the two are completed and the importance of each factor based on other factors, the experts analyzed and then the rate of adaptation have been calculated. The data analysis using the Analytic Hierarchy Process (AHP) and to identify the characteristics of the Delphi technique was used to analyze the hierarchy.

\section{AHP Hierarchical Analysis during the Following Steps}

The first step, paired comparisons: comparative tables produced by the tree hierarchy, including preferred pair wise comparison using the same scale, much less important, less important, fairly important, more important, much more important, very (much) more important was designed. When comparing the two, at the beginning of importance should be mutually determined by rank, then the corresponding numerical value is given in the table comparison, the diameter of the matrix with the number one show because they prefer to own both systems. is the same. Comparison matrix in AHP A matrix inversion, which means that if, for example, prefer a 5 economical to competitors, then the competitors preferred economic factor is 1 to 5 . Thus another table is obtained by comparing the numbers of each row in the column to the experts, combine and become a more unified, and according to decide. One of the best ways to combine comparative table of the respondents is the use of the geometric mean. Will help to realize the geometric mean, keeping in mind the judgment of each member of the judging group will compare the test. Since the paired comparisons data will be compared, the geometric mean is mathematically the best way for them. The reverse of the comparison matrix makes good use out of it most of all. As time and Akzl (inventor of the method of hierarchical analysis) have shown the geometric mean, the most appropriate mathematical formula to combine judgment in AHP Is. Because the average property on the reverse of paired comparison matrix maintains. Given that aij ${ }^{(\mathrm{K})}$ components related to $\mathrm{k}$ person to compare. For example i_factor is to j_factor. So, it will be counted:

$$
a_{i j}=\left\lceil\sum_{i}^{n} a_{i j} a_{i j}\right\rceil
$$

(Relationship 1)

Relationship (2), applied that the views of members be equal importance. Then, according to the matrix table together and thus make up a table comparing the views of our members. The second step is extracted from the table of the comparison group priorities: Priority to extract tables only considers the comparison group. To determine the priority of the normal and weighted average is used. There are several methods for normalization. The AHP Comparative table to normalize the relationship (2) is used:

$$
r_{i j}=\frac{a_{i j}}{\sum_{i=1}^{m} a_{i j}}
$$

(Relationship 2)

The normal component, $a_{i j}$, which represents the priority (importance) of each choice of rival. Third, choose the best option for each row of the matrix in amounts corresponding best choice values multiplied and weighted average for each specific factor at this stage is the best option that represents the highest number selected. The fourth step, the rate of adaptation: the importance of AHP In addition to combining different levels of the hierarchy of decision and considering several factors in calculating the adjustment rate (CR) is used.

\section{RESULTS}

To answer the research question and to determine the factors influencing the strategic plan and prioritize their marketing, the action was paired comparison matrix composed primarily of experts in the factors affecting 
Table 1. Matrix paired comparisons between factors in strategic planning, marketing

\begin{tabular}{ccccc}
\hline Factors & Prospects & Customer Relations & Competition & Economic factors \\
\hline Economic factors & 2.14 & 1.49 & 2.28 & 0.1 \\
\hline Competition & 1.61 & 0.86 & 0.1 & 0.61 \\
\hline Customer Relations & 1.92 & 0.1 & 1.99 & 1.32 \\
\hline Prospects & 0.1 & 1.42 & 1.84 & 1.45 \\
\hline
\end{tabular}

Table 2. Normalized data matrix factors in strategic planning, marketing

\begin{tabular}{ccccc}
\hline Factors & Prospects & Customer Relations & Competition & Economic factors \\
\hline Economic factors & 0.321 & 0.312 & 0.321 & 0.228 \\
\hline Competition & 0.241 & 0.180 & 0.141 & 0.139 \\
\hline Customer Relations & 0.288 & 0.210 & 0.280 & 0.103 \\
\hline Prospects & 0.150 & 0.298 & 0.259 & 0.331 \\
\hline
\end{tabular}

Table 3. Prioritization of factors and their parameters

\begin{tabular}{|c|c|c|c|}
\hline Priority & Factors & Parameters factors & Weight ratio \\
\hline \multirow{8}{*}{1} & \multirow{8}{*}{ Economic factors } & Government monetary policy & 0.286 \\
\hline & & Monetary policy & 0.284 \\
\hline & & The government's currency policy & 0.246 \\
\hline & & Bank and government trade policy & 0.194 \\
\hline & & Fiscal Policy Bank & 0.179 \\
\hline & & Bank currency policy & 0.122 \\
\hline & & Trade policy and commercial banks & 0.111 \\
\hline & & Fiscal Policy Bank & 0.102 \\
\hline \multirow{4}{*}{2} & \multirow{4}{*}{ Competition } & Internal actual competitors & 0.206 \\
\hline & & Internal potential competitors & 0.202 \\
\hline & & External actual competitors & 0.199 \\
\hline & & External potential competitors & 0.198 \\
\hline \multirow{5}{*}{3} & \multirow{5}{*}{ Customer Relations } & Social factors & 0.208 \\
\hline & & Exchange of information with customers & 0.203 \\
\hline & & Sales activities and providing banking services & 0.201 \\
\hline & & Customers trust & 0.201 \\
\hline & & Monitor the Bank's relations with customers & 0.185 \\
\hline \multirow{5}{*}{4} & \multirow{5}{*}{ Prospects } & Bank plans to expand electronic services & 0.218 \\
\hline & & Bank Marketing Programs & 0.204 \\
\hline & & Bank plans to expand branches & 0.201 \\
\hline & & Bank foreign exchange policies in the future & 0.192 \\
\hline & & Dynamic activity in stock & 0.185 \\
\hline
\end{tabular}

marketing strategic planning on the basis of a questionnaire Ghavamin Bank (2), based on factors of importance from 1 to 9 is the most important aspect to very high importance, polls and scores assigned by SPSS software Survey results are calculated as shown in Table 1.

After the conclusion of the experts, questionnaire design, and (3) the experts were asked to compare a couple of components of their pay. The scores were normalized to the results in Table 2.

The results of the ranking of the four factors in the strategic planning of marketing in the province Ghavamin Bank showed that economic factors in order of importance, competitors, customers and prospects through the eyes of experts have been affected. Rate adjustment: adjustment rate calculated by the Software Expertise Choice 0.00 times, and it is less than 0.01 , it can be said that there has been adapting very well in comparison. It's about all the steps involved in four major categories of indicators have been identified to repeat the results of ranking the criteria for each factor is shown in Table 3.

As 'Table 3 indicates the parameters and elements involved in economic agents 'state policy' as a priority and "fiscal policy of the bank" is the last priority. The parameters and elements involved in the competition "internal potential competitors" in first priority "External potential competitors" is the last priority. The parameters and elements involved in the relationship with clients "social factors" first priority "to monitor the Bank's relations with customers" is the last priority. The parameters and elements involved in the prospects of the bank "Bank plans to expand electronic services" as a priority and "dynamic activity on the exchange" is the last priority.

\section{DISCUSSION AND CONCLUSION}

The complexity of management decisions and conflicts arising from the interaction of nature and issues of communication in a group decision-making hierarchy and the presence of a large and experienced senior managers for some time to adapt to the problem of others have a reduction choice quality of decisions strategy is appropriate. 
AHP technique In connection with the strategy set by the young directors a chance to get rid of the problems traditionally granted to group decision-making using practical proposals in order to increase the quality of decisions walk. One of the most important ways to achieve sustainable competitive advantage is the process of strategic planning. Through strategic planning that can be virtualized into the distant future in the minds of senior managers and the simulation result using futures to achieve a sustainable competitive advantage. On the other hand the importance of marketing and its decisive role in the activities of the organization, one of the most important approaches to strategic planning, strategic planning, and marketing is that almost all of the organization should be given to this unit and output the results of the program self-regulate (Sadeghi et al., 2011). This article is to review and identify appropriate strategies marketing plan Ghavamin Bank in Mazandaran province Analytical Hierarchy Process (AHP) Paid.

The results and findings of the study showed that the order of priority in strategic planning, marketing factors that should be considered by managers Ghavamin Bank are: economic factors, competition, communication with customers and prospects, and future plans. The findings of this study was to identify factors with the general study of Claycomb et al (2000) full compliance, it is also in their study of economic factors, the relationship with customers, competitors and perspectives as the factors identified in the strategic planning of marketing but these factors have not been prioritized. Books et al (2005) and consider the appropriateness of manufactured goods to the demands of the buyers of the most important factors in marketing planning have that same kind of relationship with customers that have been identified in this study. Pistol (2010) customer feedback and customer assumptions about important factors in strategic planning, marketing stated. This means that online marketing plan to executives and decision-makers to pay special attention to their customers and their needs and tastes.

On the other hand, since Ghavamin Bank is a financial institution, attached to economic factors and economic policy and the economic situation in the region and the world as well as special attention to the findings of the present study was also confirmed this economic factors of the most important a factor that must be considered in strategic planning, marketing database. Another factor that results and findings necessary to pay attention to it and make it the most important factors considered in the strategic planning of marketing at Ghavamin Bank, and pay attention to their competitors. Ghavamin Bank as a financial institution and credit in the banking system does not have a long history, both internal and external to the actual competitors who are now working in the financial and banking as well as potential competitors that may be added competitors lined, special attention and planning its marketing strategy, it is also considered. But since all banks and landscapes for future marketing programs, and all their activities, Ghavamin Bank have drawn attention to this in their marketing strategic plans and determines that the future of marketing activities the need to introduce new services itself.

\section{Suggestions}

According to the findings of the present study proposals for strategic planning and marketing in the province and to some extent other banks Ghavamin Bank offered:

1. According to the Central Bank in setting monetary policy and the government's strategic marketing plan.

2. According to competitors, including public and private banks and financial and credit institutions in strategic marketing plan.

3. Communicate with customers and enable the bank to identify $R \& D$ needs and opinions of banking services provided to clients and their expectations of the future and use this information in the regulation of the Strategic Plan the marketing mix.

4. Due to new banking technologies and services around the world and plans to offer these services in the future direction of the Bank's strategic marketing plan.

5. The use of experts and managers in strategic planning and marketing team.

6. Consult with experts in the Bank's strategic marketing plan of the bank.

\section{REFERENCES}

Abdul, F. A. (2013). Strategic marketing planning and the Nigerian banking industry. Journal of Research in National Development, $11(1), 145-151$.

Books, S., Ansari, M. and Nasseri Taheri, M. (2005). Selecting the appropriate marketing mix using AHP technique Marketing strategic planning approach (Case Study: Marjan Tile Co.). Journal of Administrative Sciences and Economics, University of Isfahan, 17(1), 79-92.

Claycomb, C., Germain, R. and Droge, C. (2000). The effects of formal strategic marketing planning on the industrial firm's configuration, structure, exchange patterns and performance. Industrial Marketing Management, 29, 219-234. https://doi.org/10.1016/S0019-8501(98)00055-8

Gungaphul, M. and Boolaky, M. (2009). Entrepreneurship and marketing: An exploratory study in Mauritius. Journal of Chinese Entrepreneurship, 1(3), 209-226. https://doi.org/10.1108/17561390910999506 
Horner, S. and Swarbrook, J. (2005). Leisure marketing: A global perspective. New York: Elsevier Butter worthHeinemann.

Pistol, G. (2010). The role and importance of the strategic planning in bank marketing. Annals of Spiru Haret University, Economic Series, 1(2), 153-161.

Rahman nature, H. (2004). Strategic management theorists thought. Tabatabai, Tehran, Iran.

Sadeghi, M., Sobhani, M. S. and Traveler, F. (2011). Effectiveness analysis of the effectiveness of strategic planning, marketing information systems (case study bank). Beyond management, 5(18), 25-51.

Samadi, M. and Fine, I. (2009). Marketing strategic planning and choosing the right strategy using AHP technique (Ahwaz Pipe Mills). Journal of Behavior, 16(35), 69-82.

Venus, A. and Jazani Khani, J. (2007). Business ethics in Islam. Journal of Knowledge and Development, $13,43-61$. 